\title{
Role of DNA Methylation in Development of Cardiovascular Diseases, Resulting in a Sudden Cardiac Death (Review)
}

DOI: $10.17691 / \mathrm{stm} 2022.14 .1 .08$

Received March 9, 2021

A.A. Ivanova, MD, PhD, Senior Researcher, Laboratory for Molecular Genetics of Internal Diseases ${ }^{1}$

S.V. Maksimova, Student ${ }^{2}$;

A.A. Gurazheva, Junior Researcher, Laboratory for Molecular Genetics of Internal Diseases ${ }^{1}$

${ }^{1}$ Institution of Internal and Preventive Medicine - Branch of the Federal Research Center Institute of Cytology and Genetics, Siberian Branch of the Russian Academy of Sciences, 175/1 B. Bogatkova St., Novosibirsk, 630089, Russia;

${ }^{2}$ Novosibirsk State Medical University, 52 Krasny Prospekt, Novosibirsk, 630091, Russia

An effective system to diagnose predisposition to development of sudden cardiac death (SCD) is required in order to determine the risk of developing a sudden fatal outcome well in advance of the onset thereof, including in people with asymptomatic cardiovascular disease, as well as to implement early preventive measures that can result in a decrease in the population mortality from cardiovascular diseases. Thus, the search for SCD risk markers becomes a topical issue for modern health care.

According to recent studies, epigenetic mechanisms of heredity, and DNA methylation above all, play an important role in development of many diseases. The review provides the results of recent foreign and Russian studies on identification of a link between DNA methylation and development of cardiovascular diseases being the basis for SCD (IHD, cardiomyopathies, heart rhythm disturbances). The major part of the review is dedicated to studying DNA methylation in IHD, which is the most epigenetically explored nosology at the moment. Attention is also paid to studies of the DNA methylation role in development of acute coronary syndrome and myocardial infarction, which have development mechanisms similar to those of SCD. There were only few studies on identification of a link between DNA methylation and cardiomyopathies and cardiac arrhythmias conducted, however, an association of specific genes methylation with the explored nosologies was revealed. The review also provides pathogenetic substantiations of the possibilities to use epigenetic markers of cardiovascular diseases as SCD markers.

Thus, it has been established that study of genes the methylation of which is associated with IHD (CTH, PLCB1, PTX3, MMP9, FN1, F2RL3, ABCB1, FOXP3, GDF15, IL6, CASR), with lipid metabolism disorders and atherosclerosis (CETP, CCL2, SREBF2, TIMP1), as well as with heart rhythm disturbances (SCN5A and KCNQ1), may be most promising in relation to SCD.

Key words: sudden cardiac death; DNA methylation; ischemic heart disease; cardiomyopathy; myocardial infarction; acute coronary syndrome; heart rhythm disturbances.

How to cite: Ivanova A.A., Maksimova S.V., Gurazheva A.A. Role of DNA methylation in development of cardiovascular diseases, resulting in a sudden cardiac death (review). Sovremennye tehnologii v medicine 2022; 14(1): 83, https://doi.org/10.17691/stm2022.14.1.08

This is an open access article under the CC BY 4.0 license (https://creativecommons.org/licenses/by/4.0/).

\section{Introduction}

Despite a recent significant progress in prevention of ischemic heart disease (IHD) and cardiac failure, the problem of high mortality from cardiovascular diseases has not yet been solved [1, 2]. A large share (25 to 50\%) in the cardiovascular mortality breakdown is taken by the sudden cardiac death (SCD) $[1,3]$. According to recommendations of the European Society of Cardiology, the "sudden cardiac death" term should be used in case of a sudden lethal outcome (non-traumatic, unexpected death within $1 \mathrm{~h}$ after the onset of symptoms in an assumed healthy person or within $24 \mathrm{~h}$ from the moment when the deceased was last seen alive if the death was unwitnessed), considering the following: whether the past history of the deceased contains an indication of a congenital or acquired potentially lethal heart disease; whether the autopsy revealed a cardiac or vascular anomaly which might have caused death; whether autopsy revealed no extracardiac causes of death (in this case, arrhythmia is the most probable cause of the lethal outcome) [1].

The dominant SCD cause in adults is chronic degenerative diseases (IHD, valvular heart diseases, heart failure), of which IHD is the first $(75 \%)$, whereas heart rhythm disturbances and cardiomyopathy are seen less often (15\%) [1, 4, 5]. In younger people and children, SCD development is promoted by

Corresponding author: Anastasia A. Ivanova, e-mail: ivanova_a_a@mail.ru 
cardiomyopathy, congenital heart rhythm disturbances, myocarditis, myocardial ischemia due to coronary vessel pathologies or heart failure.

Pathophysiologically, SCD may have a predisposing substrate (e.g., an anatomical substrate being regions of collagen mixed with viable cardiomyocytes after myocardial infarction, or a functional substrate represented by channelopathies in long QT syndrome), when there is a trigger, which develops ventricular tachycardia or fibrillation, less often bradyarrhythmia, asystole, or complete atrioventricular block [2, 6, 7]. It is not always possible to identify the factor that caused the heart rhythm disturbance even after a forensic medical examination of the deceased from SCD and a post-mortem molecular genetic study (according to different sources, it is possible only in $2-54 \%$ of all SCD instances) [1, 2, 7]. At that, almost $50 \%$ of people with SCD were not diagnosed with cardiovascular diseases during their lives [1].

The most promising measure in SCD prevention is stratification of individual risk of its development, including with the help of genetic markers [1]. Genetic and environmental factors contribute to the development of multifactorial SCD nosology. A large number of polymorphisms and gene mutations associated with SCD have been identified by the present day [8]. However, it is still unclear how significant genes interact at the cellular level in the SCD pathogenesis. The discovery of DNA methylation provided for studying the relationship between the genetic information embedded in the DNA sequence and the disease phenotype. Studies on DNA methylation can help explaining the mechanism of genetic information presentation in a disease pathogenesis.

\section{DNA methylation}

Epigenetic changes, including DNA methylation, form an important mechanism by which the environment can influence the genome. Epigenetic modifications are not associated with a change in the DNA nucleotide sequence, but they can affect gene expression and contribute to diseases development. During the past two decades, a lot of research has been conducted to find the connection between DNA methylation and cardiovascular diseases.

DNA methylation is usually considered in the context of a $\mathrm{CpG}$ dinucleotide sequence (CpG sites) and entails addition of a methyl group to a cytosine in this cytosine phosphate guanine dinucleotide [9]. In somatic mammalian cells, most CpG sites are methylated $(70-90 \%)$ [10]. But CpG sites in the regions of the increased CpG density (CpG islands) are generally described as sites of the decreased methylation level. DNA methylation of a gene promoter is an important factor in regulation of gene transcription [11]. It is known that hypomethylation of a gene promoter increases its expression, while hypermethylation decreases it [12].
DNA methylation stabilizes chromatin structure during transcription and can vary greatly in different tissues and throughout human life [9]. Moreover, DNA methylation depends on age, gender, and ethnicity; this process is also affected by nicotine consumption [13]. In their systematic review, Asllanaj et al. [14] showed that the level of DNA methylation depends on gender, including in case of lipid metabolism disorders and cerebrovascular accidents; gender-dependent differences were also found in the methylation of individual genes in cardiovascular pathologies. According to the authors, this may explain the different frequency of cardiovascular pathologies development risks in men and women.

DNA methylation is involved in the following processes: X-chromosome inactivation; activity of mobile retro-elements; cellular differentiation; programming, survival, fatality, and imprinting of parental genes; activity of the immune system [15]. Methyltransferases, including DNMT1, DNMT2, DNMT3a, and DNMT3b are responsible for DNA methylation. DNMT3a and DNMT3b are responsible for de novo DNA methylation. DNMT1 methyltransferase is required during DNA replication to copy information about the methylation pattern from a parent strand to a daughter strand. Passive change in methylation status is possible only by silencing DNMT1 methyltransferase function. Active change in the methylation pattern can be achieved differently. Deamination converts 5-methylated cystine to thymine, which is corrected into unmethylated cystine in case of repair synthesis. Another path involves TET1, TET2, TET3 enzymes, which can add a hydroxyl group to a methyl group, converting 5-methylcytosine to 5-hydroxymethylcytosine, cleaved by thymine DNA glycosylase. Regardless of the existing mechanisms, DNA methylation of $\mathrm{CpG}$ sites is stable for the majority of tissues [16]. In case of methylation, gene expression can be changed differently. The first way to block gene expression involves inability of transcription factors and DNA to interact in case of methylated CpG sites [15]. The second way provides for interaction with the methyl binding domain proteins methylated by $\mathrm{CpG}$ sites, including MCP2, MBD1, MBD2, MBD4, which transcribe CpG site methylation and thus stop or suppress transcription [10].

There are several major approaches to studying DNA methylation: measuring the global level of DNA methylation; study of methylation of specific candidate genes; epigenome-wide analysis of DNA methylation, including epigenome-wide association studies (EWAS) [17]. The accumulated knowledge suggests that epigenetic alterations, such as DNA methylation pathologies, may help reveal an alternative explanation for the pathophysiology of a cardiovascular disease [18]. In addition to methylation of specific genes associated with development of a particular disease, the level of genome-wide methylation is also explored, including with the help of modern next-generation sequencing technologies [19]. Genome-wide association studies 
identified many single nucleotide polymorphisms localized in non-coding segments, but still associated with diseases. It is assumed that epigenetic mechanisms can explain some of the mentioned results [20].

There were many studies related to DNA methylation for each cardiovascular phenotype. In a number of instances (for example, in case of atherosclerosis, IHD), diagnostic markers of the disease development, severity, and prognosis were determined. There were no articles on studying DNA methylation in SCD found in the available world literature, except for our pilot study [21], which showed that methylation of the $A B C A 1$ gene promoter is associated with SCD. It is known that the $A B C A 1$ (ATP binding cassette subfamily A member 1) gene encodes the protein related to cholesterol transportation. Gene inactivation by the gene promoter methylation is associated with the IHD development being the most frequent SCD substrate for the middle-aged and the elder [22].

\section{DNA methylation and ischemic heart disease}

The most explored nosology in relation to DNA methylation is ischemic heart disease [5]. The association of the disease with the global DNA hypermethylation is established. The researchers found a large number of genes the methylation of which is associated with IHD, including myocardial infarction and acute coronary syndrome (ACS). Some of these genes have been recently found (see Appendix 1). For instance, Sharma et al. [23] identified 72 hypermethylated regions in individuals with IHD as well as $6 \mathrm{CpG}$ sites, including the intronic region of the C1QL4 gene, control elements of the CCDC47 and TGFBR3 genes, the methylation of which is associated with this disease. A genome-wide methylation in patients with IHD study identified critical genes (ABCA1, DDAH2) and sequences (LINE-1 and Alu), the methylation of which is also associated with the risk of this pathology development. LINE-1 and Alu are large, high-copy retrotransposons of the human genome. The level of these elements' methylation differs significantly in patients with IHD and people from the control group [24, 25].

A case-controlled study in a group of patients with IHD (178 people) and a control group (156 people) demonstrated the association of the examined nosology with the CTH gene promoter methylation [26]. The CTH (cystathionine gamma-lyase) gene encodes a cytoplasmic enzyme that converts cystathionine to cysteine. The rs113044851 insertion-deletion polymorphism of this gene was found to reduce the risk of SCD [27]. Therefore, the CTH gene can be considered as a candidate gene for susceptibility to SCD. Guo et al. [28] showed that the level of PTX3 (pentraxin 3) gene methylation (this gene plays a role in the development of inflammation and atherogenesis) is significantly lower in the IHD group compared to the control group. The PTX3 gene encodes a protein the expression of which is induced by inflammatory cytokines in response to inflammation; this protein is also involved in angiogenesis and tissue remodeling. Several studies demonstrated a rapid increase in the concentration of the PTX3 protein in the blood plasma in patients with ACS. For instance, Tajo et al. [29] measured the level of PTX3 in individuals who died from a fatal ACS and in those who died differently. It turned out that the PTX3 concentration was higher in the ACS group with coronary thrombosis compared with the control group and the ACS groups with coronary stenosis and the heart tissue alterations typical of myocardial infarction. During a three-year follow-up [30], it was shown that the level of PTX3 in the blood of patients with the chronic heart failure is also higher compared to that of healthy individuals and correlates with the severity of the heart failure according to NYHA. Moreover, it was found that in patients with the developed endpoints (cardiac death, repeated hospitalization, higher severity of the disease) the level of PTX3 in blood plasma is higher than in individuals without such endpoints [30]. Thus, studying of the PTX3 gene methylation in SCD may be a promising region of research when getting a positive result is highly probable as this gene is involved in angiogenesis and tissue remodeling, the PTX 3 promoter methylation association with IHD was shown, and there is information of a link between the level of its protein with ACS (including fatal ACS) and chronic heart failure (including its outcomes resulted in cardiac death).

According to the case-controlled study [31], hypomethylation of the COMT gene promoter is associated with an increased risk of IHD in men. The risk of IHD development, and especially acute myocardial infarction, also increases with hypomethylation of the IL6 gene promoter [32]. Methylation of the GCK, GALNT2, TNNT1, PLA2G7, MMP9, FOXP3, ANGPTL2, and $A B C G 1$ genes is also associated with IHD [19, 33-37]. The MMP9 gene (matrix metallopeptidase 9) is of interest from the point of view of studying methylation in SCD. The level of MMP-9 protein is associated with myocardial fibrosis in hypertrophic cardiomyopathy and the related cardiac events in women (syncope, ventricular tachycardia) [38]. Hou et al. [39] found that in the group of people with IHD, in whom according to coronary angiography the coronary artery stenosis did not exceed $50 \%$, the MMP-9 concentration was higher than in the control group and correlated with the Framingham risk score. In this regard, the authors suggest that MMP-9 levels may be helpful in identification of patients at risk related to myocardial infarction and SCD. There is also data [40] on MMP-9 association with atherosclerosis and atherosclerotic plaque instability. Thus, the MMP-9 protein can be a SCD marker, which makes the MMP9 gene promising for studying methylation in case of SCD.

In 2017, a systematic review on DNA methylation in patients with IHD was published [17]. Based on the analysis of scientific articles the authors concluded that the contribution of global DNA methylation to the 
IHD development is uncertain. At the same time, the association of some candidate genes methylation with IHD can be considered as confirmed (hypermethylation of the ESRa, ABCG1, FOXP3 genes, hypomethylation of the IL6 gene). The analysis of epigenome-wide association studies identified 84 genes that are differentially methylated in case of IHD (a third part of these genes are markers of obesity).

In 2019, an epigenome-wide association study [41] identified $52 \mathrm{CpG}$ sites associated with IHD, some of which are localized in calcium regulation genes (ATP2B2, CASR, GUCA1B, HPCAL1) and are associated with atherosclerotic plaque calcification (PTPRN2) and kidney functioning (CDH23, HPCAL1). From the point of view of SCD, the study of the CASR (calcium-sensing receptor) gene methylation related to calcium metabolism is of interest. For instance, a meta-analysis of data from exome-wide studies on chips [42] provides information about several new polymorphisms associated with the QT interval, one of which is rs1801725 of the CASR gene. Long QT syndrome, in turn, is also a risk factor for the SCD development. According to the results of a pilot epigenome-wide association study [18], there were 429 differentially methylated regions (222 hypomethylated and 207 hypermethylated) identified in patients with IHD and individuals from the control group; there was also a panel of loci with the most different methylation status created, it included mainly the genes of the HLA system and inflammation. Using the method of methyl-specific $\mathrm{PCR}$, it was found that the level of methylation of the $A B C A 1$ gene promoter is statistically significantly higher in patients with angiographically confirmed IHD $(n=110)$ compared to the control group $(n=110)$ [22]. In a large Russian study, the methylation status of the promoter regions of the TXNRD1, GSTP1, GCLM genes, 4-6 $6^{\text {th }}$ exons of the MPO gene in IHD, arterial hypertension, and acute cerebrovascular accident was studied. An insignificant decrease in the level of the GCLM and MPO genes methylation in case of IHD was found in comparison with the control group. In the event of combination of arterial hypertension and IHD, a decrease in the level of methylation was noted for all the studied genes, whereas in the event of combination of arterial hypertension, IHD, and acute cerebrovascular accident — for all genes except TXNRD1 [43]. Miao et al. [44] reported 11 differentially methylated loci localized in the BDNF, BTRC, CDH5, CXCL12, EGFR, IL6, ITGB1, PDGFRB, PIK3R1, PLCB1, and PTPRC genes in case of IHD. Only PLCB1 (phospholipase C beta 1) was studied out of these 11 genes in terms of association with SCD. For instance, our study [45] indicates an association of the single nucleotide polymorphism rs16994849 of the PLCB1 gene with SCD: the GG polymorphism genotype is a SCD risk genotype for persons under 50 years and has a protective effect for people over 50 years; AA polymorphism genotype has a protective effect in terms of SCD for persons under 50 years. It is known that an increase in PLCB1 gene expression is associated with hypertrophy of cardiomyocytes. Lin et al. [46] established an association of PLCB1 gene polymorphisms with the concentration of apolipoprotein $B$, total cholesterol, and high-density lipoprotein cholesterol in blood. Zhang et al. in their recent study [47] identified potential IHD biomarkers (FN1, PTEN, POLR3A), the expression of which is associated with the level of DNA methylation and the risk of IHD. In people with SCD, type 2 diabetes mellitus, and preserved ejection fraction, the expression of the FN1 gene (fibronectin 1) is higher than in those who died from other causes. The FN1 gene is known to be a candidate gene for IHD [48].

The KAROLA prospective cohort study [49] demonstrated an association of F2RL3 gene methylation (F2R like thrombin or trypsin receptor 3 ) with mortality in people with IHD. The F2RL3 gene encodes a proteinase-activated receptor which is involved into coagulation, inflammation, and pain response. 1206 study participants (patients who had myocardial infarction, ACS, or coronary artery surgery) were followed up for 8 years. During this period, there were 64 cardiovascular deaths and 50 deaths from other causes. Representatives of the lowest quartile of the F2RL3 gene methylation showed the adjusted odds ratio for cardiovascular death of 2.32 compared to representatives of the highest quartile, but the $95 \%$ confidence interval (0.97-5.58) was not statistically significant, whereas the odds ratio and $95 \%$ confidence interval for non-cardiovascular death and death from all causes were statistically reliable.

In a more recent study [50] of F2RL3 gene methylation (3588 patients; 10.1 years of follow-up) conducted on the basis of the ESTHER project, the odds ratio for cardiovascular death was 2.45; the 95\% confidence interval (1.28-4.68) was statistically significant. The identified association was more significant for men than for women. It was also shown that the F2RL3 gene methylation is associated with smoking, which is a risk factor for cardiovascular events [50]. Moreover, an increase in the F2RL3 gene expression in case of IHD was reported [51]. Thus, the F2RL3 gene, which is related to coagulation, can be considered as a candidate for future studies of methylation in case of SCD, as methylation of this gene is associated with IHD (the main cause of SCD in the adult population), cardiovascular death, and smoking, which is also a risk factor for SCD.

Another gene of interest in relation to $S C D$ is $A B C B 1$ (ATP binding cassette subfamily $B$ member 1 ), the hypomethylation of which is associated with less aspirin absorption, higher platelet activity, and an increased risk of ischemic events (vascular death, repeated ischemic stroke, myocardial infarction, or transient ischemic attack) in people with intracranial stenosis [52].

The most severe forms of IHD are ACS and myocardial infarction. Arrhythmias after myocardial infarction and ACS often result in SCD, which in most cases occurs when a patient has ACS at the hospital stage [53]. Soares et al. [54] found that in patients with 
ACS (190 persons) the level of global DNA methylation is higher compared to healthy people (75 persons) of the same gender and age. At that, in patients with a low result on the TIMI score, the level of DNA methylation is higher compared to patients at high and medium risk.

In the study of genome-wide methylation in ACS, 19 hypermethylated loci and 17 hypomethylated genes that may be markers of ACS were identified, however, the association of methylation with nosology in the case-control study using methyl-specific PCR was confirmed only for the SMAD3 locus [55]. Another epigenome-wide study using the whole blood of 102 patients with ACS and 101 people in the control group identified $47 \mathrm{CpG}$ sites associated with ACS. 26 of them correlate with the level of expression of the corresponding genes, including the IL6R, FASLG, and CCL18 genes [56]. It has been demonstrated [34] that in patients with ACS, the ANGPTL2 gene, which encodes a circulating pro-inflammatory protein, is hypomethylated, whereas the level of protein in blood is increased compared to healthy persons of the same gender and age.

The increased methylation of the highly conserved region of the FOXP3 gene (FOXP3-TSDR), which determines regulatory $T$ cells functioning, is associated with an increased risk of adverse outcomes (cardiovascular death, myocardial infarction, repeated coronary surgery) in patients with ACS and the severity of atherosclerosis (a decrease in regulatory $\mathrm{T}$ cells functioning and number results in its advance) [57]. Decreased expression and hypermethylation of the FOXP3 gene are seen in case of IHD [17, 58]. Thus, taking into account the FOXP3 gene involvement in development of IHD, ACS, adverse outcomes of ACS (including cardiovascular death), and atherosclerosis, it is possible to find a positive relation between methylation of this gene, in particular its highly conserved FOXP3-TSDR region, and SCD.

According to ICD-10, death from myocardial infarction (I21-I22) is not related to SCD (I46.1) [59], however, SCD is a frequent outcome of a previous infarction due to its recurrence or heart rhythm disturbances [53]. With regard to myocardial infarction, DNA methylation of both the genome and specific genes was studied. In an epigenome-wide association study of cardiovascular pathology conducted in Sweden [60], 211 differentially methylated CpG sites were identified in patients with myocardial infarction (196 genes, 42 of them are associated with heart function), including the RYR2 and KCNN1 genes involved in ion transportation, and cardiogenesis genes (including the GDF15 gene). In a large multistage study based on the KORA, NAS, and InCHIANTI projects, 9 CpG sites altered after myocardial infarction were identified; these were localized in the DHCR24, KCNN1, $A L K B H 1$, and $L R P 8$ genes [61]. The LRP8 (low-density lipoprotein receptor-related protein 8 ) gene encodes a low-density lipoprotein receptor that also functions as a receptor for the ApoE protein. Some single nucleotide polymorphisms of the LRP8 gene are associated with myocardial infarction, IHD, and early unifamilial IHD $[62,63]$. In this regard, the $L R P 8$ gene may also be of interest when studying methylation in case of SCD. In an epigenome-wide association study conducted in Japan [13], the researchers found that the cg07786668 site of the ZFHX3 gene and the cg17218495 site of the SMARCA4 gene are statistically significant in association with myocardial infarction. Single nucleotide polymorphisms of the ZFHX3 (zinc finger homeobox 3) gene are associated with atrial fibrillation, which can cause SCD [64].

It was demonstrated that methylation of the $A L D H 2$ gene promoter plays an important role in protection of the myocardium from ischemia; an association of myocardial infarction with methylation of the GDF15 gene was identified [65]. The GDF15 (growth differentiation factor 15) gene encodes the protein involved in the cellular stress response to an injury. A higher level of the GDF-15 protein increases the risk of SCD within $24 \mathrm{~h}$ after myocardial infarction [66] as well as after ACS [67]. Furthermore, GDF-15 is associated with fatal arrhythmic events and all-cause mortality in case of dilated cardiomyopathy [68].

Association of myocardial infarction with methylation of the GNAS-AS1 gene in men and women and of the INS-IGF2 gene in women was also demonstrated [69]. In an epigenome-wide case-controlled study [70] (206 persons with myocardial infarction and 206 persons in the control group) based on the EPICOR project, three differentially methylated loci (the TCN2 gene promoter, the 5'UTR region of the CBS gene, the AMT gene) were identified in men and two (PON1 gene, 5'UTR region of the $C B S$ gene) - in women, whose methylation was reduced due to myocardial infarction. Hypomethylation of the IL6 gene promoter is also associated with this nosology [32]. The study of 27-year-old monozygotic male twins discordant for myocardial infarction showed hypomethylation of the $L D A H, A P O B, A C S M 2 A, A C S M 5$, ACSF3, CES1, CES1P1, AFG3L2, ISCU, SEC14L2, MTTP genes in a twin without myocardial infarction (twins have the same work and have no risk factors associated with pathology) [71].

Thus, it is possible to identify a number of promising candidate genes to study methylation thereof in SCD from the considered genes, the methylation of which is associated with IHD, myocardial infarction, and ACS:

the CTH and PLCB1 genes, polymorphic variants of which are associated with SCD;

the PTX3 gene, as the level of the PTX3 protein in the blood is associated with fatal ACS related to coronary thrombosis, or cardiac death related to a chronic heart failure;

the MMP9 gene, as the protein encoded by the gene is considered as a potential risk marker for SCD;

the FN1 gene, the expression of which is associated with SCD, type 2 diabetes mellitus, and preserved left ventricular ejection fraction; 
the F2RL3 gene, the methylation of which is associated with cardiovascular death in case of IHD;

the $A B C B 1$ gene, the methylation of which is mentioned in relation to a cardiac death in case of intracranial stenosis;

the FOXP3 gene, the methylation of which is associated with a cardiovascular death after ACS;

the GDF15 gene, as an increased level of GDF-15 raises up the risk of $S C D$ after ACS, myocardial infarction and in dilated cardiomyopathy;

the CASR gene, the methylation of which is associated with IHD (see Appendix 2).

The IL6 gene (interleukin 6), the methylation of which is associated with SCD and myocardial infarction, can also be a possible candidate gene to study methylation in case of SCD [17, 44]. Based on the Cardiovascular Health Study, more than 5000 people had their IL-6 level measured. A 17-year follow-up of participants showed that the IL-6 level is associated with the risk of SCD [72]. The same result was received earlier on the basis of the PRIME study after a 10-year follow-up of participants [73].

\section{DNA methylation and atherosclerosis}

Atherosclerosis of the coronary vessels is a direct substrate of IHD, which is the most frequent cause of SCD. According to the Russian National Guidelines for Determination of the Risk and Prevention of Sudden Cardiac Death, high cholesterol is a minor risk factor for SCD, whereas prescription of statins is a preventive measure for SCD in patients with IHD [3]. Therefore, searching global scientific studies on DNA methylation in atherosclerosis and lipid metabolism disorders can be useful to find candidate genes, the methylation of which is associated with SCD.

The epigenome-wide association study by Hedman et al. [20] provided for identification of $33 \mathrm{CpG}$ sites associated with the level of lipids (of which 25 were new, the methylation of which had not been previously associated with the lipid spectrum). One of the sites belongs to the SREBF2 (sterol regulatory element binding transcription factor 2) gene, the methylation of which is associated with the level of total cholesterol. According to the data available, the rs2228314 polymorphism of the SREBF2 gene is associated with the risk of SCD [74].

Yamada et al. [75] studied postmortem DNA methylation in patients with atherosclerosis $(n=128)$. The level of methylation was measured in pairs in atherosclerotic and healthy tissues of the aorta of the same person. There were $16 \mathrm{CpG}$ sites identified which were located in genes not previously associated with atherosclerosis (FHIT, WNT8B, HOXA10, HOXC-AS2, ZNF609, HOXA-AS3, GDF6, TBX20, HOXA6, TUBA4A/ TUBA4B, CCDC62, MYOM2, RNASE6).

Another epigenome-wide study [76] revealed that methylation of the $\mathrm{CpG}$ site of the cg06500161 locus of the ABCG1 gene is associated with the levels of high-density lipoprotein cholesterol and triglycerides. The level of methylation of this locus is higher in persons who had myocardial infarction in history compared to healthy people. In addition to the ABCG1 gene locus, there were several $\mathrm{CpG}$ sites belonging to the genes associated with the level of triglycerides (TXNIP, SREBF1, CPT1A, MIR33B/SREBF1, APOA5) and low-density lipoprotein cholesterol (TNIP1) identified [76]. In atherosclerosis, triglycerides level is also associated with hypomethylation of the CCL2 (C-C motif chemokine ligand 2) gene promoter, which encodes a cytokine with chemotactic activity to monocytes and basophils as well as is involved in development of atherosclerosis [19]. It is known that an increase in CCL2 gene expression in atherosclerotic plaques is closely correlated with SCD [77]. It was demonstrated that the SMAD7 gene methylation can be a new predictive marker and therapeutic target in case of atherosclerosis because the gene promoter is hypermethylated both in atherosclerotic plaques and in the blood of patients with atherosclerosis, which positively correlates with the level of homocysteine and the degree of atherosclerotic plaque progression [78].

There was a series of studies conducted in Russia to study DNA methylation in atherosclerosis. For instance, it was identified [79] that the level of LINE-1 methylation is significantly reduced in peripheral blood leukocytes in patients with clinically apparent atherosclerosis compared to healthy persons, and this indicator is even lower in carotid artery cells affected by atherosclerosis. Arterial wall cells from the region of atherosclerotic plaques of the coronary arteries are characterized by higher levels of methylation in the promoter region of the PNPLA2 gene compared to the unaffected wall of the internal thoracic arteries [80]. The level of methylation of the MIR10B and MIR21 genes in leukocytes of patients with atherosclerosis is higher than in leukocytes of the control group [81].

Some studies revealed an association of the SLAMF7, MIR10B, and ABCA1 genes methylation with atherosclerosis [82-84]. The $L P L$ gene methylation is associated with high-density lipoprotein cholesterol level, whereas of the CETP gene - with the level of low-density lipoprotein cholesterol in men and women, and with the level of high-density lipoprotein cholesterol and triglycerides only in men [85]. There was a study conducted based on the DIABHYCAR project with participation of 3124 patients with type 2 diabetes mellitus and high cardiovascular risk. It was identified that the TaqIB polymorphism of the CETP gene is associated with SCD in patients with type 2 diabetes mellitus: the B1B1 homozygotes have a higher risk of SCD than carriers of the B2 allele. The CETP (cholesteryl ester transfer protein) gene encodes a plasma protein involved in the transportation of cholesterol from high-density lipoproteins to other lipoproteins [86]. 
It was demonstrated that the ABCA1, ACAT1, and TIMP1 genes have high specificity and sensitivity for early diagnosis of atherosclerosis [24]. It is accepted that the level of the TIMP-1 protein may be a marker of mortality in patients with cardiac failure undergoing cardiac resynchronization therapy [87].

As can be seen from the above, the study of methylation of the CETP, CCL2, and SREBF2 genes may be of most interest in relation to SCD, as it is associated with lipid metabolism imbalances and atherosclerosis, whereas polymorphisms of the CETP, SREBF2 genes and CCL2 expression are associated with SCD. The TIMP1 gene is also of interest because the protein encoded by this gene is accepted as a marker of death in case of a chronic heart failure.

\section{DNA methylation and heart rhythm disturbances}

In about $40 \%$ of cases, sudden death in people under 35 years of age remains unexplained after a forensic examination. Heart rhythm disturbances, primarily long QT syndrome, Brugada syndrome, and catecholaminergic polymorphic ventricular tachycardia are considered to be the most likely causes of a sudden death. The SCD development in case of rhythm disturbances may be related to dysfunction of ion channels (impaired opening, closing, and functioning thereof), intracellular concentration of such ions as calcium, which, on the background of certain predisposing factors, causes rapid development of tachycardia or ventricular fibrillation and death [88].

DNA methylation studies were conducted for some heart rhythm disturbance syndromes. For instance, methylation of the KCNQ1 gene was studied in a cohort of patients with a prolonged QT interval [89].

In case of the H558R (rs1805124) polymorphism of the SCN5A gene in persons with Brugada syndrome, the level of SCN5A gene expression is higher, and its methylation level is lower compared to people without the H558R polymorphism; DNA for analysis was extricated from the right atrium tissue $(n=30)$ [90]. Polymorphisms of the KCNQ1 and SCN5A genes, according to some researches, are related to development of SCD. The KCNQ1 (potassium voltage-gated channel subfamily $\mathrm{Q}$ member 1) gene encodes a voltage-gated potassium channel responsible for the repolarization phase of the cardiac action potential. Mutations in the gene are associated with development of the type 1 long QT syndrome or unifamilial atrial fibrillation. Single nucleotide polymorphisms of the gene (rs10798, rs8234) are associated with an increased risk of SCD in patients with the long QT syndrome [91]. Liu et al. [92] in their meta-analysis demonstrated that single nucleotide polymorphisms rs12296050 and rs2283222 of the KCNQ1 gene and rs11720524 of the SCN5A gene are associated with SCD. The SCN5A (sodium voltage-gated channel alpha subunit 5) gene encodes an integral membrane protein being a sodium channel subunit. Gene mutations result in development of the type 3 long QT syndrome. According to Lahtinen et al. [93], the rs41312391 polymorphism of the SCN5A gene is associated with SCD.

A genome-wide study of DNA methylation [94] provided for identification of differentially methylated genes in patients with atrial fibrillation compared with persons with the sinus heart rhythm (primarily genes associated with inflammation, ion transportation, fibrosis, and lipid metabolism). Another epigenome-wide association study [9] found $7 \mathrm{CpG}$ sites associated with atrial fibrillation located near the WFIKKN2, STRN, SSU72, BLCAP, DPYSL4, RBBP5, and WDR37 genes. The overall level of DNA methylation was significantly higher in the atrial fibrillation group compared to the sinus heart rhythm group. In case of atrial fibrillation, the promoter of the NPRA gene (natriuretic peptide receptor gene) is hypermethylated, whereas the expression of the gene is reduced [95]. With atrial fibrillation, the LINC00472 (long intergenic non-protein coding RNA 472) gene is also hypermethylated. It is accepted that its expression is associated with the expression of miR-24 RNA, which in turn regulates the expression of the JPH2 (junctophilin 2) gene that affects the expression of the RYR2 (ryanodine receptor 2) gene involved in the pathogenesis of atrial fibrillation. In addition to an increased level of LINC00472 methylation, one can see an increase in the miR-24 expression level and a decrease in the expression of LINC00472 [96]. Hypermethylation of the PITX2 (paired like homeodomain 2) gene is associated with atrial fibrillation [97]. The analysis of researches revealed that the number of group participants is low, DNA samples were extricated from the myocardium of the right [95] or left atrium [94, 96, 97], or venous blood [9].

With this regard, the study of methylation of the SCN5A and KCNQ1 genes (related to the long QT syndrome, a frequent cause of unexplained sudden death), polymorphisms of which are associated with SCD, will be the most promising approach for SCD.

\section{DNA methylation and cardiomyopathies}

The most frequent forms of cardiomyopathies leading to SCD include hypertrophic and dilated cardiomyopathies; arrhythmogenic right ventricular and restriction cardiomyopathies are less common. Pathogenetically, in case of cardiomyopathy, SCD can occur due to a mechanical underlying cause (obstruction of the outflow tract of the left ventricle in hypertrophic cardiomyopathy) or development of malignant arrhythmia (dilated cardiomyopathy). The "ischemic cardiomyopathy" term is also used to describe myocardial dysfunction caused by severe IHD [4].

One of the early studies [98] identified 51 hypermethylated promoters and 6 hypomethylated promoters of genes associated with dilated cardiomyopathy and expression of these genes, 
including the AURKB, BTNL9, CLDN5, and TK1 genes, which were not previously described as involved in dilated cardiomyopathy. An epigenomic association study provided for revealing 59 loci, the methylation of which was significantly associated with dilated cardiomyopathy [99].

In case of ischemic cardiomyopathy, hypermethylation of the ASB1 gene was established; the gene methylation status is associated with the left ventricular ejection fraction, stroke volume, as well as with end-systolic and end-diastolic size of the left ventricle [100]. Li et al. in their study [101] identified three more genes (SLC2A1, MPV17L, PLEC) with different methylation status were in ischemic cardiomyopathy.

Targeted bisulfite sequencing in patients with the heart failure related to an ischemic, dilated and hypertrophic cardiomyopathy revealed 195 unique differentially methylated regions (5 for hypertrophic obstructive cardiomyopathy, 151 for dilated cardiomyopathy, 55 for ischemic cardiomyopathy). Subsequent analysis of expression revealed 6 genes (HEY2, MSR1, MYOM3, COX17, CTGF, MMP2), the expression of which is associated with their methylation pattern and heart failure [102].

\section{Conclusion}

Knowledge of gene polymorphisms and mutations only is not enough to understand their role in development of multifactorial diseases, as it does not provide for understanding of the ways in which changes in the DNA structure manifest themselves in the pathogenesis of the disease.

DNA methylation is an important form of epigenetic modification that can impact gene expression without changing the DNA nucleotide sequence. At that, DNA methylation is influenced by environmental factors, it depends on gender, age, and other phenotype characteristics, as well as lifestyle. The genes methylation status differs in various body tissues. DNA methylation is not only involved in the regular cell activities but may also be significant in pathogenesis of diseases. Therefore, epigenetic studies are extremely important for studying the genetic basis of diseases with a hereditary predisposition.

There were few studies of DNA methylation in sudden cardiac death conducted, but DNA methylation was studied for underlying diseases (IHD, cardiomyopathy, heart rhythm disturbances). There were papers on measuring the overall level of DNA methylation published, epigenome-wide studies, and studies of methylation of individual genes conducted. Analysis of their results provides for identification of the most promising genes in relation to sudden cardiac death, the methylation of which is associated with IHD (CTH, PLCB1, PTX3, MMP9, FN1, F2RL3, ABCB1, FOXP3, GDF15, IL6, and CASR), with lipid metabolism disorders and atherosclerosis (CETP, CCL2, SREBF2, and
TIMP1), with heart rhythm disturbances (SCN5A and KCNQ1).

Epigenome-wide association studies aimed at identification of unique differentially methylated loci for sudden cardiac death, the methylation of which was not previously associated with cardiovascular diseases, may also become significant. Studying the level of global DNA methylation will also expand scientific knowledge about epigenetic changes in case of a sudden cardiac death. The data obtained during the study of DNA methylation in case of a sudden cardiac death will permit to advance deeper in understanding of the mechanisms of SCD development, including the relations with genes, their polymorphic variants and mutations. Moreover, studying of DNA methylation is required for development of systems for diagnosis, prevention, and treatment of cardiovascular diseases leading to a sudden cardiac death.

Authors' contribution: A.A. Ivanova - the concept and idea of the review, writing the "DNA methylation and ischemic heart disease" section, final review and approval of the manuscript; A.A. Gurazheva - writing the "DNA methylation and atherosclerosis" section and compilation of the appendices; S.V. Maksimova - writing the "DNA methylation and heart rhythm disturbances" and "DNA methylation and cardiomyopathies" sections.

Study funding. The reported study was funded by RFBR, project number 20-115-50004.

Conflicts of interest. No conflicts of interest are declared.

\section{References}

1. Priori S.G., Blomström-Lundqvist C., Mazzanti A., Blom N., Borggrefe M., Camm J., Elliott P.M., Fitzsimons D., Hatala R., Hindricks G., Kirchhof P., Kjeldsen K., Kuck K.H., Hernandez-Madrid A., Nikolaou N., Norekvål T.M., Spaulding C., Van Veldhuisen D.J.; ESC Scientific Document Group. 2015 ESC Guidelines for the management of patients with ventricular arrhythmias and the prevention of sudden cardiac death: the Task Force for the management of patients with ventricular arrhythmias and the prevention of sudden cardiac death of the European Society of Cardiology (ESC). Endorsed by: Association for European Paediatric and Congenital Cardiology (AEPC). Eur Heart J 2015; 36(41): 2793-2867, https://doi.org/10.1093/eurheartj/ehv316.

2. Hindricks G., Lenarczyk R., Kalarus Z., Döring M., Shamloo A.S., Dagres N. Prevention of sudden cardiac death by the implantable cardioverter-defibrillator. Pol Arch Intern Med 2018; 128(12): 764-770, https://doi.org/10.20452/ pamw.4386.

3. Shlyakhto E.V., Arutyunov G.P., Belenkov Yu.N., Ardashev A.V. National guidelines for risk assessment and prevention of sudden cardiac death. Arhiv vnutrennej mediciny 2013; 4: 5-15.

4. Kariki O., Antoniou C.K., Mavrogeni S., Gatzoulis K.A. Updating the risk stratification for sudden cardiac death in cardiomyopathies: the evolving role of cardiac magnetic resonance imaging. An approach for the electrophysiologist. 
Diagnostics (Basel) 2020; 10(8): 541, https://doi.org/10.3390/ diagnostics10080541.

5. Rahola J.T., Kiviniemi A.M., Ukkola O.H., Tulppo M.P., Junttila M.J., Huikuri H.V., Kenttä T.V., Perkiömäki J.S. Temporal variability of T-wave morphology and risk of sudden cardiac death in patients with coronary artery disease. Ann Noninvasive Electrocardiol 2021; 26(3): e12830, https://doi. org/10.1111/anec.12830.

6. van der Bijl P., Delgado V., Bax J.J. Imaging for sudden cardiac death risk stratification: current perspective and future directions. Prog Cardiovasc Dis 2019; 62(3): 205-211, https:// doi.org/10.1016/j.pcad.2019.04.005.

7. Tsuda T., Fitzgerald K.K., Temple J. Sudden cardiac death in children and young adults without structural heart disease: a comprehensive review. Rev Cardiovasc Med 2020; 21(2): 205-216, https://doi.org/10.31083/j.rcm.2020.02.55.

8. Osman J., Tan S.C., Lee P.Y., Low T.Y., Jamal R. Sudden cardiac death (SCD) - risk stratification and prediction with molecular biomarkers. J Biomed Sci 2019; 26(1): 39, https://doi.org/10.1186/s12929-019-0535-8.

9. Lin H., Yin X., Xie Z., Lunetta K.L., Lubitz S.A., Larson M.G., Ko D., Magnani J.W., Mendelson M.M., Liu C., McManus D.D., Levy D., Ellinor P.T., Benjamin E.J. Methylomewide association study of atrial fibrillation in Framingham Heart Study. Sci Rep 2017; 7: 40377, https://doi.org/10.1038/ srep40377.

10. Tao H., Shi K.H., Yang J.J., Li J. Epigenetic mechanisms in atrial fibrillation: new insights and future directions. Trends Cardiovasc Med 2016; 26(4): 306-318, https://doi. org/10.1016/j.tcm.2015.08.006.

11. Nazarenko M.S., Markov A.V., Lebedev I.N., Freidin M.B., Sleptcov A.A., Koroleva I.A., Frolov A.V., Popov V.A., Barbarash O.L., Puzyrev V.P. A comparison of genome-wide DNA methylation patterns between different vascular tissues from patients with coronary heart disease. PLoS One 2015; 10(4): e0122601, https://doi.org/10.1371/ journal.pone.0122601.

12. Wang X., Liu A.H., Jia Z.W., Pu K., Chen K.Y., Guo H. Genome-wide DNA methylation patterns in coronary heart disease. Herz 2018; 43(7): 656-662, https://doi.org/10.1007/ s00059-017-4616-8.

13. Nakatochi M., Ichihara S., Yamamoto K., Naruse K., Yokota S., Asano H., Matsubara T., Yokota M. Epigenomewide association of myocardial infarction with DNA methylation sites at loci related to cardiovascular disease. Clin Epigenetics 2017; 9: 54, https://doi.org/10.1186/s13148-017-0353-3.

14. Asllanaj E., Zhang X., Ochoa Rosales C., Nano J., Bramer W.M., Portilla-Fernandez E., Braun K.V.E., GonzalezJaramillo V., Ahrens W., Ikram A., Ghanbari M., Voortman T., Franco O.H., Muka T., Glisic M. Sexually dimorphic DNAmethylation in cardiometabolic health: a systematic review. Maturitas 2020; 135: 6-26, https://doi.org/10.1016/j. maturitas.2020.02.005.

15. Tabaei S., Tabaee S.S. DNA methylation abnormalities in atherosclerosis. Artif Cells Nanomed Biotechnol 2019; 47(1): 2031-2041, https://doi.org/10.1080/21691401.2019.16 17724.

16. Yu J., Zeng C., Wang Y. Epigenetics in dilated cardiomyopathy. Curr Opin Cardiol 2019; 34(3): 260-269, https://doi.org/10.1097/hco.0000000000000616.

17. Fernández-Sanlés A., Sayols-Baixeras S., Subirana I., Degano I.R., Elosua R. Association between DNA methylation and coronary heart disease or other atherosclerotic events: a systematic review. Atherosclerosis 2017; 63: 325-333, https:// doi.org/10.1016/j.atherosclerosis.2017.05.022.

18. Banerjee S., Ponde C.K., Rajani R.M., Ashavaid T.F. Differential methylation pattern in patients with coronary artery disease: pilot study. Mol Biol Rep 2019; 46(1): 541-550, https://doi.org/10.1007/s11033-018-4507-y.

19. Duan L., Liu C., Hu J., Liu Y., Wang J., Chen G., Li Z., Chen $\mathrm{H}$. Epigenetic mechanisms in coronary artery disease: the current state and prospects. Trends Cardiovasc Med 2018; 28(5): 311-319, https://doi.org/10.1016/j.tcm.2017.12.012.

20. Hedman Å.K., Mendelson M.M., Marioni R.E., Gustafsson S., Joehanes R., Irvin M.R., Zhi D., Sandling J.K., Yao C., Liu C., Liang L., Huan T., McRae A.F., Demissie S., Shah S., Starr J.M., Cupples L.A., Deloukas P., Spector T.D., Sundström J., Krauss R.M., Arnett D.K., Deary I.J., Lind L., Levy D., Ingelsson E. Epigenetic patterns in blood associated with lipid traits predict incident coronary heart disease events and are enriched for results from genome-wide association studies. Circ Cardiovasc Genet 2017; 10(1): e001487, https:// doi.org/10.1161/circgenetics.116.001487.

21. Ivanova A.A., Gurazheva A.A., Akinshina E.I., Maksimova S.V., Malyutina S.K., Novoselov V.P., Rodina I.A., Khamovich O.V., Maksimov V.N. ABCA1 gene promoter methylation and sudden cardiac death. Bulleten $\square$ sibirskoj mediciny 2020; 19(4): 80-85, https://doi.org/10.20538/16820363-2020-4-80-85.

22. Ghaznavi H., Mahmoodi K., Soltanpour M.S. A preliminary study of the association between the ABCA1 gene promoter DNA methylation and coronary artery disease risk. Mol Biol Res Commun 2018; 7(2): 59-65, https://doi. org/10.22099/mbrc.2018.28910.1312.

23. Sharma P., Garg G., Kumar A., Mohammad F., Kumar S.R., Tanwar V.S., Sati S., Sharma A., Karthikeyan G., Brahmachari V., Sengupta S. Genome wide DNA methylation profiling for epigenetic alteration in coronary artery disease patients. Gene 2014; 541(1): 31-40, https://doi.org/10.1016/j. gene.2014.02.034.

24. Duan L., Hu J., Xiong X., Liu Y., Wang J. The role of DNA methylation in coronary artery disease. Gene 2018; 646: 91-97, https://doi.org/10.1016/j.gene.2017.12.033.

25. Muka T., Koromani F., Portilla E., O'Connor A., Bramer W.M., Troup J., Chowdhury R., Dehghan A., Franco O.H. The role of epigenetic modifications in cardiovascular disease: a systematic review. Int J Cardiol 2016; 212: 174-183, https://doi.org/10.1016/j.ijcard.2016.03.062.

26. Giannakopoulou E., Konstantinou F., Ragia G., Tavridou A., Karaglani M., Chatzaki E., Papapetropoulos A., Mikroulis D., Manolopoulos V.G. Epigenetics-by-sex interaction for coronary artery disease risk conferred by the cystathionine Y-lyase gene promoter methylation. OMICS 2017; 21(12): 741748, https://doi.org/10.1089/omi.2017.0149.

27. Zhou W., Yang Q., Yu H., Zhang Q., Zou Y., Chen X., Yang Z., Qu Y., Tan R., Li L., Zhu S., He Y., Luo B., Gao Y. Association between an indel polymorphism within CTH and the risk of sudden cardiac death in a Chinese population. Leg Med (Tokyo) 2020; 46: 101736, https://doi.org/10.1016/j. legalmed.2020.101736.

28. Guo T.M., Huang L.L., Liu K., Ke L., Luo Z.J., Li Y.Q., Chen X.L., Cheng B. Pentraxin 3 (PTX3) promoter methylation associated with PTX3 plasma levels and neutrophil to lymphocyte ratio in coronary artery disease. J Geriatr Cardiol 2016; 13(8): 712-717, https://doi.org/10.11909/j.issn.16715411.2016.08.010. 
29. Tojo M., Shintani-Ishida K., Tsuboi H., Nakamura M., Idota N., Ikegaya H. Postmortem plasma pentraxin 3 is a useful marker of fatal acute coronary syndrome. Sci Rep 2019; 9(1): 8090, https://doi.org/10.1038/s41598-019-44472-0.

30. Liu H., Guo X., Yao K., Wang C., Chen G., Gao W., Yuan J., Yu W., Ge J. Pentraxin-3 predicts long-term cardiac events in patients with chronic heart failure. Biomed Res Int 2015; 2015: 817615, https://doi.org/10.1155/2015/817615.

31. Zhong J., Chen X., Wu N., Shen C., Cui H., Du W., Zhang Z., Feng M., Liu J., Lin S., Zhang L., Wang J., Chen X., Duan S. Catechol-O-methyltransferase promoter hypomethylation is associated with the risk of coronary heart disease. Exp Ther Med 2016; 12(5): 3445-3449, https://doi. org/10.3892/etm.2016.3757.

32. Zuo H.P., Guo Y.Y., Che L., Wu X.Z. Hypomethylation of interleukin-6 promoter is associated with the risk of coronary heart disease. Arq Bras Cardiol 2016; 107(2): 131-136, https:// doi.org/10.5935/abc.20160124.

33. Guay S.P., Légaré C., Brisson D., Mathieu P., Bossé Y., Gaudet D., Bouchard L. Epigenetic and genetic variations at the TNNT1 gene locus are associated with HDL-C levels and coronary artery disease. Epigenomics 2016; 8(3): 359-371, https://doi.org/10.2217/epi.15.120.

34. Nguyen A., Mamarbachi M., Turcot V., Lessard S., Yu C., Luo X., Lalongé J., Hayami D., Gayda M., Juneau M., Thorin-Trescases N., Lettre G., Nigam A., Thorin E. Lower methylation of the ANGPTL2 gene in leukocytes from postacute coronary syndrome patients. PLoS One 2016; 11(4): e0153920, https://doi.org/10.1371/journal.pone.0153920.

35. Jiang D., Zheng D., Wang L., Huang Y., Liu H., Xu L., Liao Q., Liu P., Shi X., Wang Z., Sun L., Zhou Q., Li N., Xu L., Le Y., Ye M., Shao G., Duan S. Elevated PLA2G7 gene promoter methylation as a gender-specific marker of aging increases the risk of coronary heart disease in females. PLoS One 2013; 8(3): e59752, https://doi.org/10.1371/journal.pone.0059752.

36. Zhou J., Chen L., Yang X., Huang X., Wang Z., Peng P., Lian J. Preliminary study of the relationship between promoter methylation of the ANGPTL2 gene and coronary heart disease. J Clin Lab Anal 2018; 33(3): e22702, https://doi.org/10.1002/ jcla.22702.

37. Peng P., Wang L., Yang X., Huang X., Ba Y., Chen X., Guo J., Lian J., Zhou J. A preliminary study of the relationship between promoter methylation of the ABCG1, GALNT2 and HMGCR genes and coronary heart disease. PLoS One 2014; 9(8): e102265, https://doi.org/10.1371/journal.pone.0102265.

38. Münch J., Avanesov M., Bannas P., Säring D., Krämer E., Mearini G., Carrier L., Suling A., Lund G., Patten M. Serum matrix metalloproteinases as quantitative biomarkers for myocardial fibrosis and sudden cardiac death risk stratification in patients with hypertrophic cardiomyopathy. J Card Fail 2016; 22(10): 845-850, https://doi.org/10.1016/j. cardfail.2016.03.010.

39. Hou Z.H., Lu B., Gao Y., Cao H.L., Yu F.F., Jing N., Chen X., Cong X.F., Roy S.K., Budoff M.J. Matrix metalloproteinase-9 (MMP-9) and myeloperoxidase (MPO) levels in patients with nonobstructive coronary artery disease detected by coronary computed tomographic angiography. Acad Radiol 2013; 20(1): 25-31, https://doi. org/10.1016/j.acra.2012.07.014.

40. González-Herrera L., Márquez-Ruiz A.B., Serrano M.J., Ramos V., Lorente J.A., Valenzuela A. mRNA expression patterns in human myocardial tissue, pericardial fluid and blood, and its contribution to the diagnosis of cause of death.
Forensic Sci Int 2019; 302: 109876, https://doi.org/10.1016/j. forsciint.2019.109876.

41. Agha G., Mendelson M.M., Ward-Caviness C.K., Joehanes R., Huan T., Gondalia R., Salfati E., Brody J.A., Fiorito G., Bressler J., Chen B.H., Ligthart S., Guarrera S., Colicino E., Just A.C., Wahl S., Gieger C., Vandiver A.R., Tanaka T., Hernandez D.G., Pilling L.C., Singleton A.B., Sacerdote C., Krogh V., Panico S., Tumino R., Li Y., Zhang G., Stewart J.D., Floyd J.S., Wiggins K.L., Rotter J.I., Multhaup M., Bakulski K., Horvath S., Tsao P.S., Absher D.M., Vokonas P., Hirschhorn J., Fallin M.D., Liu C., Bandinelli S., Boerwinkle E., Dehghan A., Schwartz J.D., Psaty B.M., Feinberg A.P., Hou L., Ferrucci L., Sotoodehnia N., Matullo G., Peters A., Fornage M., Assimes T.L., Whitsel E.A., Levy D., Baccarelli A.A. Blood leukocyte DNA methylation predicts risk of future myocardial infarction and coronary heart disease. Circulation 2019; 140(8): 645-657, https://doi.org/10.1161/ circulationaha.118.039357.

42. Bihlmeyer N.A., Brody J.A., Smith A.V., Warren H.R., Lin H., Isaacs A., Liu C.T., Marten J., Radmanesh F., Hall L.M., Grarup N., Mei H., Müller-Nurasyid M., Huffman J.E., Verweij N., Guo X., Yao J., Li-Gao R., van den Berg M., Weiss S., Prins B.P., van Setten J., Haessler J., Lyytikäinen L.P., Li M., Alonso A., Soliman E.Z., Bis J.C., Austin T., Chen Y.I., Psaty B.M., Harrris T.B., Launer L.J., Padmanabhan S., Dominiczak A., Huang P.L., Xie Z., Ellinor P.T., Kors J.A., Campbell A., Murray A.D., Nelson C.P., Tobin M.D., Bork-Jensen J., Hansen T., Pedersen O., Linneberg A., Sinner M.F., Peters A., Waldenberger M., Meitinger T., Perz S., Kolcic I., Rudan I., de Boer R.A., van der Meer P., Lin H.J., Taylor K.D., de Mutsert R., Trompet S., Jukema J.W., Maan A.C., Stricker B.H.C., Rivadeneira F., Uitterlinden A., Völker U., Homuth G., Völzke H., Felix S.B., Mangino M., Spector T.D., Bots M.L., Perez M., Raitakari O.T., Kähönen M., Mononen N., Gudnason V., Munroe P.B., Lubitz S.A., van Duijn C.M., Newton-Cheh C.H., Hayward C., Rosand J., Samani N.J., Kanters J.K., Wilson J.G., Kääb S., Polasek O., van der Harst P., Heckbert S.R., Rotter J.I., Mook-Kanamori D.O., Eijgelsheim M., Dörr M., Jamshidi Y., Asselbergs F.W., Kooperberg C., Lehtimäki T., Arking D.E., Sotoodehnia N. ExomeChip-wide analysis of 95626 individuals identifies 10 novel loci associated with QT and JT intervals. Circ Genom Precis Med 2018; 11(1): e001758, https://doi. org/10.1161/circgen.117.001758.

43. Bushueva O.Yu., Barysheva E.M., Markov A.V., Koroleva Yu.A., Churkin E.O., Nazarenko M.S., Polonikov A.V., Ivanov V.P. Molecular and epigenetic mechanisms of the involvement of redox-homeostasis genes in the development of various cardiovascular diseases. Medicinskaa genetika 2020; 19(5): 66-68, https://doi.org/10.25557/2073-7998.2020. 05.66-68.

44. Miao L., Yin R.X., Zhang Q.H., Hu X.J., Huang F., Chen W.X., Cao X.L., Wu J.Z. Integrated DNA methylation and gene expression analysis in the pathogenesis of coronary artery disease. Aging (Albany NY) 2019; 11(5): 1486-1500, https://doi.org/10.18632/aging.101847.

45. Ivanova A.A., Maksimov V.N., Malyutina S.K., Novoselov V.P., Savchenko S.V., Voevoda M.I. Association of the mononucleotide polymorphisms rs62116755 of gene GACAT3, rs12170546 of gene PARVB, rs16994849 of gene PLCB1, rs78143315 of gene PDCD6IP with sudden cardiac death. Rossijskij kardiologiceskij zurnal 2017; 10: 23-28, https://doi.org/10.15829/1560-4071-2017-10-23-28. 
46. Lin Y.J., Chang J.S., Liu X., Tsang H., Chien W.K., Chen J.H., Hsieh H.Y., Hsueh K.C., Shiao Y.T., Li J.P., Lin C.W., Lai C.H., Wu J.Y., Chen C.H., Lin J.G., Lin T.H., Liao C.C., Huang S.M., Lan Y.C., Ho T.J., Liang W.M., Yeh Y.C., Lin J.C., Tsai F.J. Genetic variants in PLCB4/PLCB1 as susceptibility loci for coronary artery aneurysm formation in Kawasaki disease in Han Chinese in Taiwan. Sci Rep 2015; 5: 14762, https://doi.org/10.1038/srep14762.

47. Zhang X., Xiang Y., He D., Liang B., Wang C., Luo J., Zheng F. Identification of potential biomarkers for CAD using integrated expression and methylation data. Front Genet 2020; 11: 778, https://doi.org/10.3389/fgene.2020.00778.

48. Patel M., Rodriguez D., Yousefi K., John-Williams K., Mendez A.J., Goldberg R.B., Lymperopoulos A., Tamariz L.J., Goldberger J.J., Myerburg R.J., Junttila J., Shehadeh L.A. Osteopontin and LDLR are upregulated in hearts of sudden cardiac death victims with heart failure with preserved ejection fraction and diabetes mellitus. Front Cardiovasc Med 2020; 7 : 610282, https://doi.org/10.3389/fcvm.2020.610282.

49. Breitling L.P., Salzmann K., Rothenbacher D., Burwinkel B., Brenner H. Smoking, F2RL3 methylation, and prognosis in stable coronary heart disease. Eur Heart J 2012; 33(22): 2841-2848, https://doi.org/10.1093/eurheartj/ehs091.

50. Zhang Y., Yang R., Burwinkel B., Breitling L.P., Holleczek B., Schöttker B., Brenner H. F2RL3 methylation in blood DNA is a strong predictor of mortality. Int $\mathrm{J}$ Epidemiol 2014; 43(4): 1215-1225, https://doi.org/10.1093/ije/dyu006.

51. Indumathi B., Oruganti S.S., Naushad S.M., Kutala V.K. Probing the epigenetic signatures in subjects with coronary artery disease. Mol Biol Rep 2020; 47(9): 6693-6703, https:// doi.org/10.1007/s11033-020-05723-w.

52. Li X., Zhao K., Ma N., Sun S., Miao Z., Zhao Z. Association of ABCB1 promoter methylation with aspirin exposure, platelet function, and clinical outcomes in Chinese intracranial artery stenosis patients. Eur J Clin Pharmacol 2017; 73(10): 1261-1269, https://doi.org/10.1007/s00228-0172298-z.

53. Revishvili A.Sh., Neminushchiy N.M., Batalov R.E., Gilyarov M.Yu., Golitsyn S.P., Davtyan K.V., Dumpis Ya.Yu., Didenko M.V., Zenin S.A., Ivanitskiy E.A., Komolyatova V.N., Kravtsova L.A., Krivolapov S.N., Kuzovlev A.N., Kuptsov V.V., Lebedev D.S., Lebedeva V.K., Linchak R.M., Lomidze N.N., Makarov L.M., Mironov N.Yu., Medvedev M.M., Mikhaylov E.N., Nedbaykin A.M., Nesterenko L.Yu., Romanov A.B., Rzaev F.G., Solokhin Yu.A., Tatarskiy R.B., Kharlap M.S., Chapurnykh A.V., Shlevkov N.B., Shubik Yu.V., Yashin S.M., Boytsov S.A., Egorov D.F., Zaklyaz'minskaya E.V., Kuznetsov V.A., Moroz V.V., Pokushalov E.A., Popov S.V., Shkol'nikova M.A. All-Russian clinical guidelines for the control of the risk of sudden cardiac arrest and sudden cardiac death, prevention and first aid. Vestnik aritmologii 2017; 89: 2-104.

54. Soares F.C.S., Amorim E.A.S., Araújo R.M., Werkhauser R.P., Diniz G.T.N., Carvalho V.D.C.V., Silva L.C.A., Montenegro S.T., Moraes C.N.L., Martins D.B.G., Montenegro S.M.L. Evaluation of the influence of global DNA methylation level in patients with acute coronary syndrome. Clin Chim Acta 2020; 511: 336-341, https://doi.org/10.1016/j. cca.2020.10.016.

55. Li D., Yan J., Yuan Y., Wang C., Wu J., Chen Q., Song J., Wang J. Genome-wide DNA methylome alterations in acute coronary syndrome. Int J Mol Med 2018; 41(1): 220-232, https://doi.org/10.3892/ijmm.2017.3220.

56. Li J., Zhu X., Yu K., Jiang H., Zhang Y., Deng S.,
Cheng L., Liu X., Zhong J., Zhang X., He M., Chen W., Yuan J., Gao M., Bai Y., Han X., Liu B., Luo X., Mei W., He X., Sun S., Zhang L., Zeng H., Sun H., Liu C., Guo Y., Zhang B., Zhang Z., Huang J., Pan A., Yuan Y., Angileri F., Ming B., Zheng F., Zeng Q., Mao X., Peng Y., Mao Y., He P., Wang Q.K., Qi L., Hu F.B., Liang L., Wu T. Genome-wide analysis of DNA methylation and acute coronary syndrome. Circ Res 2017; 120(11): 1754-1767, https://doi.org/10.1161/ circresaha.116.310324.

57. Zhu L., Jia L., Liu Z., Zhang Y., Wang J., Yuan Z., Hui R. Elevated methylation of FOXP3 (forkhead box p3)-TSDR (regulatory T-cell-specific demethylated region) is associated with increased risk for adverse outcomes in patients with acute coronary syndrome. Hypertension 2019; 74(3): 581-589, https://doi.org/10.1161/hypertensionaha.119.12852.

58. Shateri H., Fadaei R., Najafi M., Vatannejad A., Teimouri M., Zali F., Emamgholipour S., Parvaz E., Asadnia M., Doosti M. Circulating levels of IL-35 and gene expression of FOXP3 in coronary artery disease: is there any interplay between them and 25-hydroxyvitamin D3? Clin Lab 2018; 64(4): 483-490, https://doi.org/10.7754/clin. lab.2017.170930.

59. ICD-10. Ostryy infarkt miokarda (I21) [Acute myocardial infarction (I21)]. URL: https://mkb-10.com/index.php?pid=8073.

60. Rask-Andersen M., Martinsson D., Ahsan M., Enroth S., Ek W.E., Gyllensten U., Johansson A. Epigenome-wide association study reveals differential DNA methylation in individuals with a history of myocardial infarction. Hum Mol Genet 2016; 25(21): 4739-4748, https://doi.org/10.1093/hmg/ ddw302.

61. Ward-Caviness C.K., Agha G., Chen B.H., Pfeiffer L., Wilson R., Wolf P., Gieger C., Schwartz J., Vokonas P.S., Hou L., Just A.C., Bandinelli S., Hernandez D.G., Singleton A.B., Prokisch H., Meitinger T., Kastenmüller G., Ferrucci L., Baccarelli A.A., Waldenberger M., Peters A. Analysis of repeated leukocyte DNA methylation assessments reveals persistent epigenetic alterations after an incident myocardial infarction. Clin Epigenetics 2018; 10(1): 161, https://doi.org/10.1186/s13148-018-0588-7.

62. Asif M., Bhat S., Nizamuddin S., Mustak M.S. TG haplotype in the LRP8 is associated with myocardial infarction in South Indian population. Gene 2018; 642: 225-229, https:// doi.org/10.1016/j.gene.2017.10.037.

63. Shen G.Q., Girelli D., Li L., Rao S., Archacki S., Olivieri O., Martinelli N., Park J.E., Chen Q., Topol E.J., Wang Q.K. A novel molecular diagnostic marker for familial and early-onset coronary artery disease and myocardial infarction in the LRP8 gene. Circ Cardiovasc Genet 2014; 7(4): 514-520, https://doi.org/10.1161/circgenetics.113.000321.

64. Zaw K.T.T., Sato N., Ikeda S., Thu K.S., Mieno M.N., Arai T., Mori S., Furukawa T., Sasano T., Sawabe M., Tanaka M., Muramatsu M. Association of ZFHX3 gene variation with atrial fibrillation, cerebral infarction, and lung thromboembolism: an autopsy study. J Cardiol 2017; 70(2): 180-184, https://doi.org/10.1016/j.jjcc.2016.11.005.

65. Ek W.E., Hedman A..K., Enroth S., Morris A.P., Lindgren C.M., Mahajan A., Gustafsson S., Gyllensten U., Lind L., Johansson A. Genome-wide DNA methylation study identifies genes associated with the cardiovascular biomarker GDF-15. Hum Mol Genet 2016; 25(4): 817-827, https://doi. org/10.1093/hmg/ddv511.

66. Andersson J., Fall T., Delicano R., Wennberg P., Jansson J.H. GDF-15 is associated with sudden cardiac death 
due to incident myocardial infarction. Resuscitation 2020; 152 : 165-169, https://doi.org/10.1016/j.resuscitation.2020.05.001.

67. Lindholm D., James S.K., Gabrysch K., Storey R.F., Himmelmann A., Cannon C.P., Mahaffey K.W., Steg P.G., Held C., Siegbahn A., Wallentin L. Association of multiple biomarkers with risk of all-cause and cause-specific mortality after acute coronary syndromes: a secondary analysis of the PLATO biomarker study. JAMA Cardiol 2018; 3(12): 11601166, https://doi.org/10.1001/jamacardio.2018.3811.

68. Stojkovic S., Kaider A., Koller L., Brekalo M., Wojta J., Diedrich A., Demyanets S., Pezawas T. GDF-15 is a better complimentary marker for risk stratification of arrhythmic death in non-ischaemic, dilated cardiomyopathy than soluble ST2. J Cell Mol Med 2018; 22(4): 2422-2429, https://doi.org/ 10.1111/jcmm.13540.

69. Talens R.P., Jukema J.W., Trompet S., Kremer D., Westendorp R.G., Lumey L.H., Sattar N., Putter H., Slagboom P.E., Heijmans B.T.; PROSPER Group. Hypermethylation at loci sensitive to the prenatal environment is associated with increased incidence of myocardial infarction. Int J Epidemiol 2012; 41(1): 106-115, https://doi.org/10.1093/ ije/dyr153.

70. Fiorito G., Guarrera S., Valle C., Ricceri F., Russo A., Grioni S., Mattiello A., Di Gaetano C., Rosa F., Modica F., lacoviello L., Frasca G., Tumino R., Krogh V., Panico S., Vineis P., Sacerdote C., Matullo G. B-vitamins intake, DNAmethylation of one carbon metabolism and homocysteine pathway genes and myocardial infarction risk: the EPICOR study. Nutr Metab Cardiovasc Dis 2014; 24(5): 483-488, https://doi.org/10.1016/j.numecd.2013.10.026.

71. Koseler A., Ma F., Kilic I.D., Morselli M., Kilic O., Pellegrini M. Genome-wide DNA methylation profiling of blood from monozygotic twins discordant for myocardial infarction. In Vivo 2020; 34(1): 361-367, https://doi.org/10.21873/ invivo. 11782

72. Hussein A.A., Gottdiener J.S., Bartz T.M., Sotoodehnia N., DeFilippi C., See V., Deo R., Siscovick D., Stein P.K., Lloyd-Jones D. Inflammation and sudden cardiac death in a community-based population of older adults: the Cardiovascular Health Study. Heart Rhythm 2013; 10(10): 1425-1432, https://doi.org/10.1016/j.hrthm.2013.07.004.

73. Empana J.P., Jouven X., Canouï-Poitrine F., Luc G., Tafflet M., Haas B., Arveiler D., Ferrieres J., Ruidavets J.B., Montaye M., Yarnell J., Morange P., Kee F., Evans A., Amouyel P., Ducimetiere P. C-reactive protein, interleukin 6, fibrinogen and risk of sudden death in European middle-aged men: the PRIME study. Arterioscler Thromb Vasc Biol 2010; 30(10): 2047-2052, https://doi.org/10.1161/ atvbaha.110.208785.

74. Ivanova A.A., Maksimov V.N., Orlov P.S., Ivanoschuk D.E., Savchenko S.V., Voevoda M.I. Association of various genetic markers of cardiovascular diseases and sudden cardiac death in men. Rossijskij kardiologiceskij zurnal 2014; 10: 40-45, https://doi.org/10.15829/1560-4071-2014-1040-45.

75. Yamada Y., Horibe H., Oguri M., Sakuma J., Takeuchi I., Yasukochi Y., Kato K., Sawabe M. Identification of novel hyperor hypomethylated $\mathrm{CpG}$ sites and genes associated with atherosclerotic plaque using an epigenome-wide association study. Int J Mol Med 2018; 41(5): 2724-2732, https://doi. org/10.3892/ijmm.2018.3453.

76. Pfeiffer L., Wahl S., Pilling L.C., Reischl E., Sandling J.K., Kunze S., Holdt L.M., Kretschmer A., Schramm K., Adamski J.,
Klopp N., Illig T., Hedman Å.K., Roden M., Hernandez D.G., Singleton A.B., Thasler W.E., Grallert H., Gieger C., Herder C., Teupser D., Meisinger C., Spector T.D., Kronenberg F., Prokisch H., Melzer D., Peters A., Deloukas P., Ferrucci L., Waldenberger M. DNA methylation of lipid-related genes affects blood lipid levels. Circ Cardiovasc Genet 2015; 8(2): 334-342, https://doi. org/10.1161/circgenetics.114.000804.

77. Kuang Y.Y., Chen X.X., Wang C.C., Ye K., Wang Y., Shi Y.H. Expression of monocyte chemotactic protein-1 and its receptor in sudden coronary death. Fa Yi Xue Za Zhi 2014; 30(6): 413-415, 418.

78. Wei L., Zhao S., Wang G., Zhang S., Luo W., Qin Z., Bi X., Tan Y., Meng M., Qin J., Qin H., Tian D., Zhang A. SMAD7 methylation as a novel marker in atherosclerosis. Biochem Biophys Res Commun 2018; 496(2): 700-705, https://doi.org/10.1016/j.bbrc.2018.01.121.

79. Markov A.V., Serebryakova V.V., Nazarenko M.S., Golubenko M.V., Barbarash O.L., Puzyrev V.P. Assessment of global DNA methylation in human atherosclerosis using methylation of retrotransposable element LINE-1. Medicinskaa genetika 2018; 17(3): 13-17.

80. Markov A.V., Nazarenko M.S., Churkin E.O., Barbarash O.L., Puzyrev V.P. Methylation of PNPLA2 lipase gene in atherosclerosis. Medicinskaa genetika 2016; 15(5): $15-17$.

81. Koroleva I.A., Zarubin A.A., Markov A.V., Kazancev A.N., Barbarash O.L., Nazarenko M.S. Analysis of the association of the methylation levels of MIR10B and MIR21 genes in blood leukocytes with advanced carotid atherosclerosis. Sibirskij zhurnal klinicheskoj i jeksperimental'noj mediciny 2018; 33(2): 77-82, https://doi.org/10.29001/2073-8552-2018-33-2-77-82.

82. Xia Z., Gu M., Jia X., Wang X., Wu C., Guo J., Zhang L., Du Y., Wang J. Integrated DNA methylation and gene expression analysis identifies SLAMF7 as a key regulator of atherosclerosis. Aging (Albany NY) 2018; 10(6): 1324-1337, https://doi.org/10.18632/aging.101470.

83. Kucher A.N., Nazarenko M.S., Markov A.V., Koroleva I.A., Barbarash O.L. Variability of methylation profiles of $\mathrm{CpG}$ sites in microRNA genes in leukocytes and vascular tissues of patients with atherosclerosis. Biochemistry (Mosc) 2017; 82(6): 698-706, https://doi.org/10.1134/ s0006297917060062.

84. Lv Y.C., Tang Y.Y., Zhang P., Wan W., Yao F., He P.P., Xie W., Mo Z.C., Shi J.F., Wu J.F., Peng J., Liu D., Cayabyab F.S., Zheng X.L., Tang X.Y., Ouyang X.P., Tang C.K. Histone methyltransferase enhancer of zeste homolog 2-mediated ABCA1 promoter DNA methylation contributes to the progression of atherosclerosis. PLoS One 2016; 11(6): e0157265, https://doi.org/10.1371/journal.pone.0157265.

85. Guay S.P., Brisson D., Lamarche B., Marceau P., Vohl M.C., Gaudet D., Bouchard L. DNA methylation variations at CETP and LPL gene promoter loci: new molecular biomarkers associated with blood lipid profile variability. Atherosclerosis 2013; 228(2): 413-420, https://doi. org/10.1016/j.atherosclerosis.2013.03.033.

86. Porchay-Baldérelli I., Péan F., Bellili N., Jaziri R., Marre M., Fumeron F.; DIABHYCAR Study Group. The CETP TaqIB polymorphism is associated with the risk of sudden death in type 2 diabetic patients. Diabetes Care 2007; 30(11): 2863-2867, https://doi.org/10.2337/dc07-0869.

87. Trucco E., Tolosana J.M., Castel M.Á., Batlle M., Borràs R., Sitges M., Guash E., Matas M., Arbelo E., Berruezo A., Brugada J., Mont L. Plasma tissue inhibitor of 
matrix metalloproteinase-1 a predictor of long-term mortality in patients treated with cardiac resynchronization therapy. Europace 2016; 18(2): 232-237, https://doi.org/10.1093/ europace/euv054.

88. Skinner J.R., Winbo A., Abrams D., Vohra J., Wilde A.A. Channelopathies that lead to sudden cardiac death: clinical and genetic aspects. Heart Lung Circ 2019; 28(1): 22-30, https://doi.org/10.1016/j.hlc.2018.09.007.

89. Coto E., Calvo D., Reguero J.R., Morís C., Rubín J.M., Díaz-Corte C., Gil-Peña H., Alosno B., Iglesias S., Gómez J. Differential methylation of IncRNA KCNQ1OT1 promoter polymorphism was associated with symptomatic cardiac long QT. Epigenomics 2017; 9(8): 1049-1057, https://doi. org/10.2217/epi-2017-0024.

90. Matsumura H., Nakano Y., Ochi H., Onohara Y., Sairaku A., Tokuyama T., Tomomori S., Motoda C., Amioka M., Hironobe N., Toshishige M., Takahashi S., Imai K., Sueda T., Chayama K., Kihara Y. H558R, a common SCN5A polymorphism, modifies the clinical phenotype of Brugada syndrome by modulating DNA methylation of SCN5A promoters. J Biomed Sci 2017; 24(1): 91, https://doi. org/10.1186/s12929-017-0397-X.

91. Earle N., Yeo Han D., Pilbrow A., Crawford J., Smith W., Shelling A.N., Cameron V., Love D.R., Skinner J.R. Single nucleotide polymorphisms in arrhythmia genes modify the risk of cardiac events and sudden death in long QT syndrome. Heart Rhythm 2014; 11(1): 76-82, https://doi. org/10.1016/j.hrthm.2013.10.005.

92. Liu X., Shi J., Xiao P. Associations between common ion channel single nucleotide polymorphisms and sudden cardiac death in adults: a MOOSE-compliant meta-analysis. Medicine (Baltimore) 2018; 97(38): e12428, https://doi.org/10.1097/ md.0000000000012428.

93. Lahtinen A.M., Noseworthy P.A., Havulinna A.S., Jula A., Karhunen P.J., Kettunen J., Perola M., Kontula K., Newton-Cheh C., Salomaa V. Common genetic variants associated with sudden cardiac death: the FinSCDgen study. PLoS One 2012; 7(7): e41675, https://doi.org/10.1371/journal. pone.0041675.

94. Zhao G., Zhou J., Gao J., Liu Y., Gu S., Zhang X., Su P. Genome-wide DNA methylation analysis in permanent atrial fibrillation. Mol Med Rep 2017; 16(4): 5505-5514, https://doi. org/10.3892/mmr.2017.7221.

95. Shen K., Tu T., Yuan Z., Yi J., Zhou Y., Liao X., Liu Q., Zhou $X$. DNA methylation dysregulations in valvular atrial fibrillation. Clin Cardiol 2017; 40(9): 686-691, https://doi. org/10.1002/clc.22715.

96. Wang L.Y., Shen H., Yang Q., Min J., Wang Q., Xi W.,
Yin L., Le S.G., Zhang Y.F., Xiao J., Wang Z.N., Ji G.Y. LncRNA-LINC00472 contributes to the pathogenesis of atrial fibrillation (Af) by reducing expression of JP2 and RyR2 via miR-24. Biomed Pharmacother 2019; 120: 109364, https://doi. org/10.1016/j.biopha.2019.109364.

97. Doñate Puertas R., Meugnier E., Romestaing C., Rey C., Morel E., Lachuer J., Gadot N., Scridon A., Julien C., Tronc F., Chapuis B., Valla C., Janin A., Pirola L., Méjat A., Rome S., Chevalier P. Atrial fibrillation is associated with hypermethylation in human left atrium, and treatment with decitabine reduces atrial tachyarrhythmias in spontaneously hypertensive rats. Trans/ Res 2017; 184: 5767.e5, https://doi.org/10.1016/j.trsl.2017.03.004.

98. Koczor C.A., Lee E.K., Torres R.A., Boyd A., Vega J.D., Uppal K., Yuan F., Fields E.J., Samarel A.M., Lewis W. Detection of differentially methylated gene promoters in failing and nonfailing human left ventricle myocardium using computation analysis. Physiol Genomics 2013; 45(14): 597605, https://doi.org/10.1152/physiolgenomics.00013.2013.

99. Meder B., Haas J., Sedaghat-Hamedani F., Kayvanpour E., Frese K., Lai A., Nietsch R., Scheiner C., Mester S., Bordalo D.M., Amr A., Dietrich C., Pils D., Siede D., Hund H., Bauer A., Holzer D.B., Ruhparwar A., Mueller-Hennessen M., Weichenhan D., Plass C., Weis T., Backs J., Wuerstle M., Keller A., Katus H.A., Posch A.E. Epigenome-wide association study identifies cardiac gene patterning and a novel class of biomarkers for heart failure. Circulation 2017; 136(16): 1528-1544, https://doi.org/10.1161/ circulationaha.117.027355.

100. Ortega A., Tarazón E., Gil-Cayuela C., MartínezDolz L., Lago F., González-Juanatey J.R., Sandoval J., Portolés M., Roselló-Lletí E., Rivera M. ASB1 differential methylation in ischaemic cardiomyopathy: relationship with left ventricular performance in end-stage heart failure patients. ESC Heart Fail 2018; 5(4): 732-737, https://doi.org/10.1002/ ehf2.12289.

101. Li B., Feng Z.H., Sun H., Zhao Z.H., Yang S.B., Yang $P$. The blood genome-wide DNA methylation analysis reveals novel epigenetic changes in human heart failure. Eur Rev Med Pharmacol Sci 2017; 21(8): 1828-1836.

102. Glezeva N., Moran B., Collier P., Moravec C.S., Phelan D., Donnellan E., Russell-Hallinan A., O'Connor D.P., Gallagher W.M., Gallagher J., McDonald K., Ledwidge M., Baugh J., Das S., Watson C.J. Targeted DNA methylation profiling of human cardiac tissue reveals novel epigenetic traits and gene deregulation across different heart failure patient subtypes. Circ Heart Fail 2019; 12(3): e005765, https:lldol. org/10.1161/circheartfailure.118.005765. 


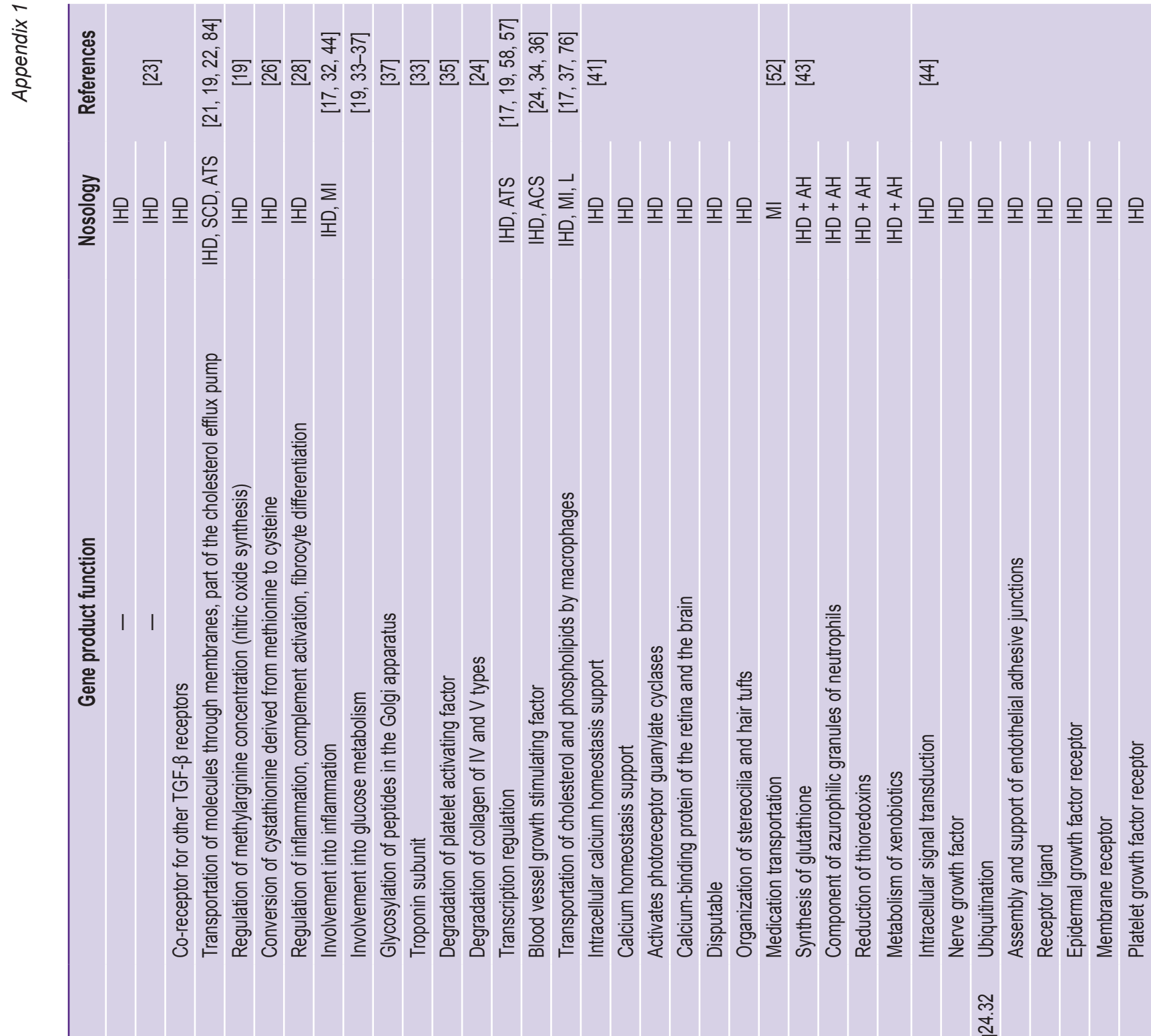

둘

흥 행

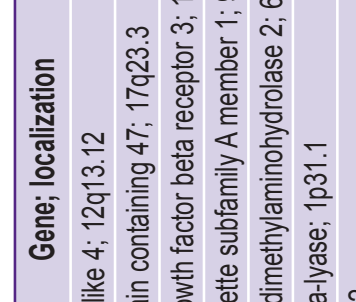

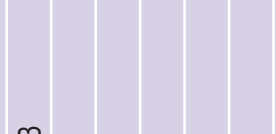
ঠ

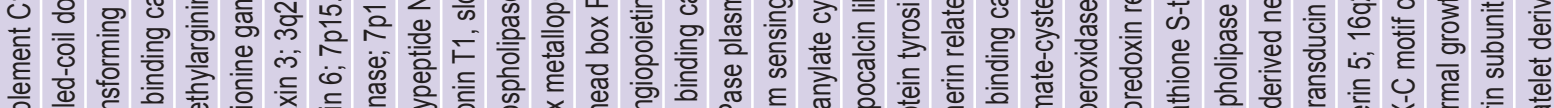
言 完

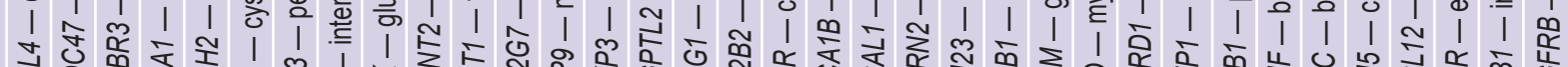

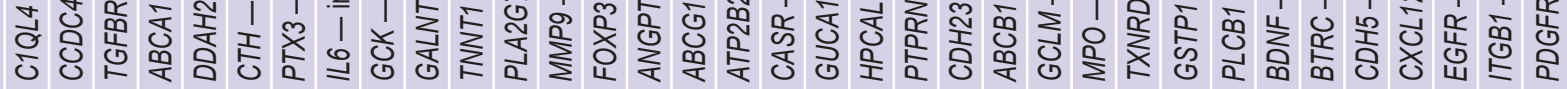




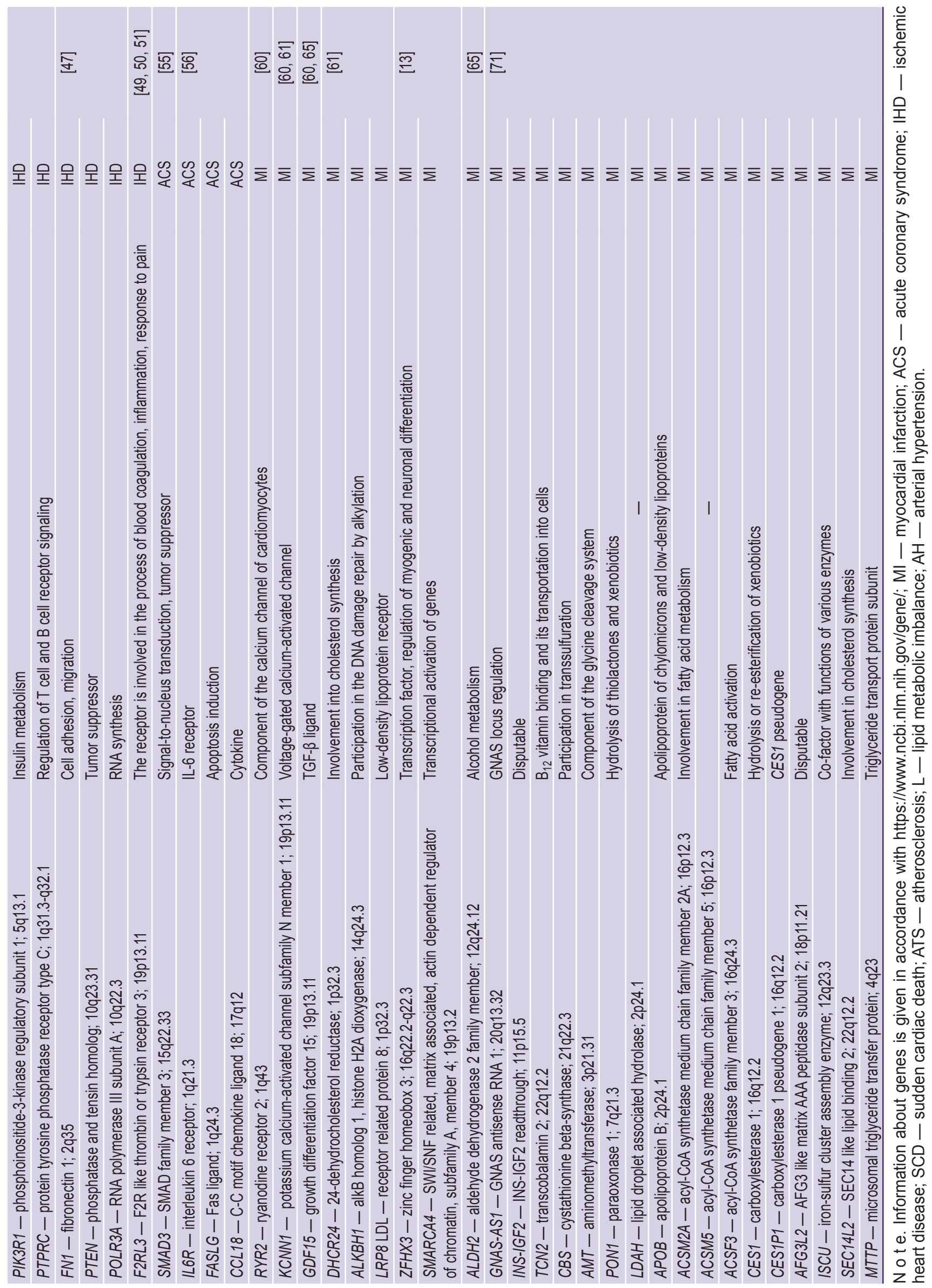




\section{REVIEWS}

$\frac{1}{x}$
$\frac{x}{d}$
$\frac{2}{2}$
$\frac{2}{\alpha}$
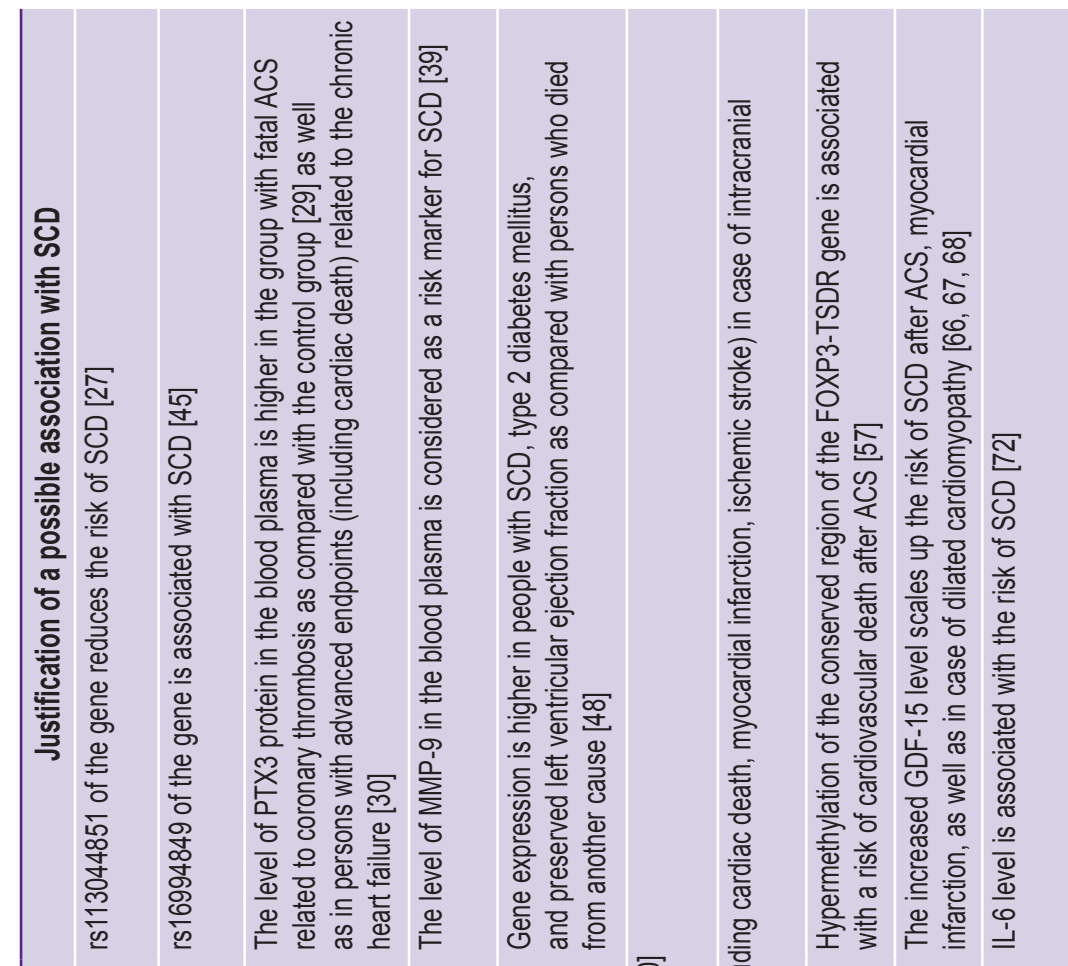

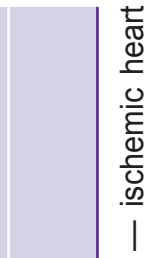

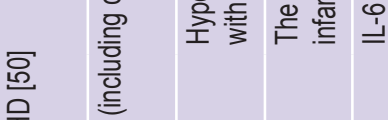

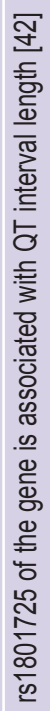

苍 몽

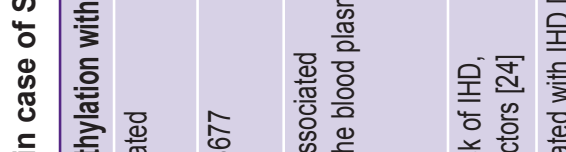

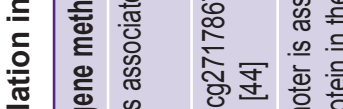

ᄎ

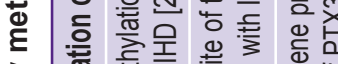

출

《)

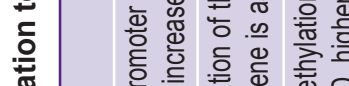

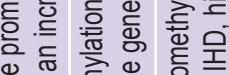

吾

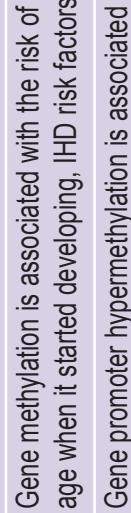

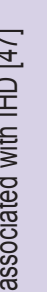

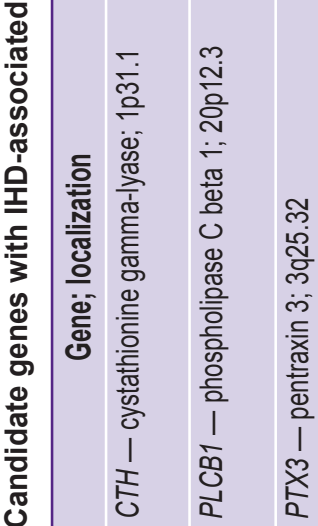

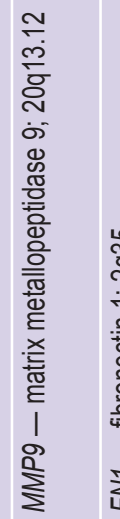

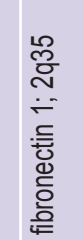

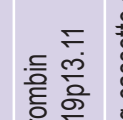

产 的

产 흠 음

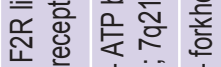

1 ।

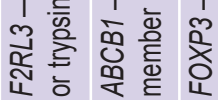

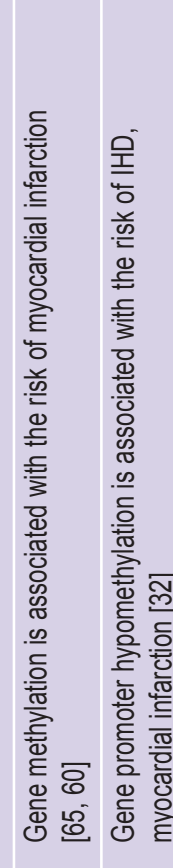

(2)

至

के

ํํำ

跑

蒾

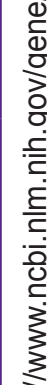

过

串

$\stackrel{\oplus}{\rightleftharpoons}$

品

造

帝

卷卷

है

言 